\title{
KAWRUH PAMOMONG: CHILDREN EDUCATION BASED ON LOCAL WISDOM IN YOGYAKARTA
}

\author{
Dhiniaty Gularso $^{1 *}$, Sugito ${ }^{2}$, Zamroni $^{3}$ \\ ${ }^{1}$ Universitas PGRI Yogyakarta, ${ }^{2,3}$ Universitas Negeri Yogyakarta Indonesia \\ *e-mail: dhiniaty@upy.ac.id
}

\begin{abstract}
Character education is the fundamental thing for one's future. In Indonesia, especially in Yogyakarta, the education of local wisdom based is Kawruh Pamomong. It is to educate children based on the truthfulness, love/passion and beautifulness or gracefulness. This research aims at studying and mapping the family education based on local wisdom Kawruh Pamomong Ki Ageng Suryomentaram in the sub-village of Balong of Timbulharjo Village in the sub-district of Sewon, Bantul Regency of Yogyakarta. Balong is a sub-district in the Southern of Yogyakarta, well-known for its KawruhJiwa in Yogyakarta. This research is conducted to gain information about how parents teach the children to think and act properly, passionate and nice. Survey method was employed in this research. The data were gained from 30 children and adolescences, in form of questionnaire, the citizens of Balong sub-district. The result of the research indicates that father and mother share the common competence in teaching and applying the Kawruh Pamomong of truthfulness and "sih", in Kawruh Pamomong of truthfulness, father has the higher competence than mother.
\end{abstract}

Keywords: children education, local wisdom, Kawruh Pamomong, Ki Ageng Suryomentaram

\section{KAWRUH PAMOMONG: PENDIDIKAN ANAK BERBASIS KEARIFAN LOKAL DI YOGYAKARTA}

\begin{abstract}
Abstrak: Pendidikan anak adalah hal yang sangat mendasar bagi masa depan seseorang. Di Indonesia khususnya di Yogyakarta, pendidikan anak berbasis kearifan lokal yang ada pada sebagian masyarakat adalah Kawruh Pamomong. Kawruh Pamomong adalah sebuah cara dan tujuan mendidik anak yang berisi benar, kasih/"sih" dan indah. Penelitian ini bertujuan untuk mengkaji dan memetakan pendidikan keluarga berbasis kearifan lokal Kawruh Pamomong Ki Ageng Suryomentaram di Dusun Balong Desa Timbulharjo Kecamatan Sewon Kabupaten Bantul Daerah Istimewa Yogyakarta. Dusun Balong adalah sebuah dusun di Yogyakarta bagian selatan yang dikenal dengan ajaran-ajaran Kawruh Jiwa di Yogyakarta. Penelitian ini dilakukan untuk menggali informasi mengenai cara orang tua mengajarkan kepada anak tentang berpikir dan bertindak benar, kasih dan indah. Metode penelitian yang digunakan adalah metode survei. Data dikumpulkan melalui angket kepada 30 anak dan remaja. Hasil penelitian menunjukkan bahwa baik ayah atau ibu memiliki kompetensi yang sama dalam mengajarkan Kawruh Pamomong benar dan "sih", sedangkan pada Kawruh Pamomong indah, ayah memiliki kompetensi yang lebih tinggi dari pada ibu.
\end{abstract}

Kata Kunci: pendidikan keluarga, kearifan lokal, Kawruh Pamomong, Ki Ageng Suryomentaram

\section{INTRODUCTION}

The successful of national education can be achieved by holding of the citizens' characters, those are tradition or culture. Japan is the world's second best national education in 2018, as informed by a research institution named The Social Progress Imperative (Wu, 2018). Japan is one of developed country, which the education still holds culture. This is the reason why Japanese has the strong character. National citizen's character is gained from education; family education is the example of amongst. For a child, family is the first education atmosphere. A child is born, grows and develops in the family which influences his characters later. According to Ghufron, Budiningsih, \& Hidayati (2017), a child experiences the real events related to the glorious values in the surround society. This real experience in society is much more effective than the instance knowledge developed in an isolated classroom (when he is at school). 
A lot of experts from all around the world studytherelationshipamongeducation, familyand culture. One of the examples is Vygotsky (18961934) from Russia which stated that children learn many things from social interaction. According to him, social interaction plays important role in children education (Harjaningrum, Inayati, Wicaksono, \& Derni, 2007). The referred social interaction is the relational process, verbal and non-verbal, between the children and adults and culture where he lives. The expert that studies the relationship between education and culture is Pierre Bourdieu (1930-2002) from France. He stated that educational process is a communication system between social order and individuals of the educational system. He is well known for his Cultural Modal Theory.

Indonesia has some educational experts, such as Kyai Ahmad Dahlan (1868-1923) with the model of Muhammadiyah education (Ishomuddin, 2014) and Ki Hadjar Dewantara (1889-1959) with the education system of among Tamansiswa. Both of them are from Yogyakarta. There is one more expert coming from Yogyakarta, that is Ki Ageng Suryomentaram (KAS). He was not really well known since his thought was more likely to discuss in informal forum, than the formal ones. It is because his thought is about the education for adults. Besides that, he chose for being separated and was not directly involved in the time of national freedom progression. KAS had simple life although he was a noble descendent of Kasultanan Yogyakarta. KAS did not write his own thought like Ki Hadjar Dewantara. Like Kyai Ahmad Dahlan, KAS thoughts were written by his children and fellows. His well-known though is Kawruh Jiwa or Happiness Knowledge. One of knowledge written by KAS is family and children education knowledge, called as Kawruh Pamomong.

This research was conducted in Balong sub-district, Timbulharjo Village, Sewon, The Regency of Bantul, Yogyakarta. Its people are known for their interest on arts and cultures. Until now, the inhabitant of this ub-district preserve the cultural traditions, such as selapan bayi, gotong royong, yasinan, sholawatan, ruwahan,wiwitan, ketoprak playing and gejog lesung. In 2015, Festival of Kawruh Jiwa was conducted in Balong Sub-District. Kawruh Jiwa is still preserved by the citizens of Balong. One of Kawruh in Kawruh Jiwa is
Kawruh Pamomong, that is the knowledge or science to educate the children. How parents in Balong Sub-District educate their children will be studied and mapped. It is expected that the results of this research, theoretically, will be the assets of Indonesian local wisdom, especially on family education. Practically, this research can be reference for Indonesian family in educating the children so they will have strong character as the citizens of Indonesia.

KAS was born in the Yogyakarta palace on $20^{\text {th }}$ May 1892 . KAS is the $55^{\text {th }}$ child among 78 children of Sri Sultan Hamengku Buwono VII, who ruled the kingdom from 1877-1921 (Sugiarto, 2015). KAS's mother name is Bendara Raden Ayu Retnomandoyo, a daughter Patih Danurejo VI. When he was a child, KAS's name is Raden Mas Kudiarmadji. When he was 18 , KAS was crowned as prince Bendoro Pangeran Harya Suryomentaram, or he was more popular as B.R.M Suryomentaram. KAS was good at problem solving which made him as the consultant of Sri Sultan Hamengku Buwono VII.

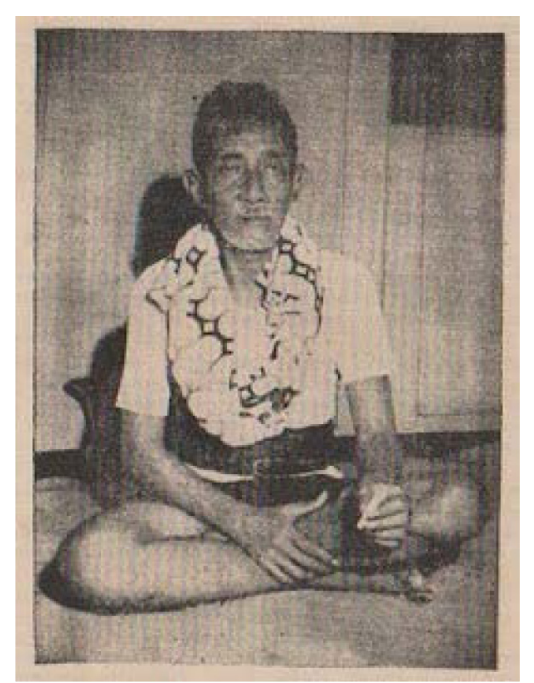

Figure 1. Ki Ageng Suryomentaram (Source: Wusana, 2017)

While he was a prince, KAS could not find happiness (Kusumawardhani, 2018). In the surrounding of the palace, KAS only found the people who commanded and were commanded. His life journey, left by his wife when he was 23 with his 40 day old baby, parents' divorce, the death of his beloved grandfather, made him to have strong will to leave his noble life and became an ordinary civilian. After the death of his wife, KAS started to learn about religion 
to Kyai Ahmad Dahlan, the founding father of Muhammadiyah (Koentjoro, 2015; Wusana, 2017). After the World War I broke out, KAS discussed the Indonesian freedom movement with Ki Hadjar Dewantara and some other figures in Yogyakarta, in which later it was well known as meeting of Selasa Kliwon. KAS is the leader and Ki Hadjar (KHD) is the secretary (Subagya, 2016; Sugiarto, 2015).

KAS started to write his thought in form of poems in 1928. His ideas were gained from observation to himself by all out-exploration about himself. The first book was titled "UranUran Beja", which is in form of Mocopat Song. This traditional song which born KAS' life teaching, which later would be known as Kawruh Jiwa or the Science of Happiness. KAS' Kawruh Jiwa consists of 6 Kawruh, those are Kawruh Beja Sawetah. Kawruh Bab Kawruh, Kawruh Bab Ungkul, Kawruh Laki Rabi, Kawruh Pangupa Jiwa and Kawruh Pamomong (Suryomentaram,1989). In this sub-chapter, the researcher would only focus on Kawruh Pamomong, as it is the topic of this study.

Kawruh Pamomong by KAS is translated into the science of education (Suryomentaram, Suastika, \& Armosentono, 1985). KAS has stated that education science is a guidance to educate the children to make them happy. He also stated that happy life indicator is that when is easy to get along and able to earn life. According to KAS, the foundation of being able to get along is love. On the other hand, quarrelsome is the foundation of being unable to get along. Quarrelsome appears when we feel that we are in the right position, others are wrong. According to him, love is something that is gained from others, it is natural and understandable that everybody thinks that he is in the right position. This is the fact of human relationship in this world.

According to the statement about love and happiness above, KAS concluded that every event comes for reason and result. If only people realize and understand the existence of cause and result, there will be no quarrel, there will be only passionate and love to each-others. For example, the poor should not be jealous to the rich, because the rich is diligent to earn something. Results that happen between them is very much natural. When the naturalness is understood by both of them, there will be no quarrelsome. There will be only the love and passionate in both of them.
Suryomentaram, et al. (1985: 123) stated that "love and passion will be achieved if there is no expectations. Those expectations consist of gold, position and power (Javanese: semat, derajat and kramat)". Love and passionate transform in form of struggle to be free from selfinterests (sepi ing pamrih), to make others happy. In love and passionate, it can be understood that every human has the same feeling, happy and sad. Meaning that, the immortal things in this world are the sad and the happiness. In educating the children, the educators should omit the expectation, so that it generates the love. Educating is an act to fulfill the students' need, not the educators'.

KAS described that the first step to educate children to gain happy life is that the children can think realistically, from what perspectives that they can state something real. Second, parents should grow the children's love and keep them away from quarrel. Third, their interests on things which are beautiful should be grown. The following will be described the suggestions from KAS regarding how to educate our children. KAS told us events or phenomena happening in our society.

Educate children to be able to think and understand the truth. When a child walks not carefully, his head impacts a flagpole. Then, he tells his parents about this. Later, parents hit back the flagpole as if it were condemned to his child. Such kind of education gives bad impact to the way of children thinking. It is impossible that inanimate object can hurt people, that it is made a reason to hurt it back. That misconception gives bad impact and impression to the child when he grows as an adult later. It is possible that he will blame the hard rain and the summer sun (Suryomentaram, et. al., 1985).

Educate children to be able to love others. A child coming home, telling his parents that a friend disturbed him. The parents protected the child by saying; "Don't get along with that friend of yours anymore because he is naughty". Such kind of education will make the child cannot find his own mistake and easy to blame others. This will give a bad impact in long term, because the love and passionate will not grow and the child will be hard to get along with others. It is better for parents to ask first why their child is disturbed. Often found that the child hard to say the truth, he tends to say that "I did nothing, but 
still, he disturbed me". If it is so, parents should tell the child that every action comes from a reason. It is not required that parents support or blame the child, it is better that the parents make the child eager to tell the truth (Suryomentaram, et al., 1985).

Educate children to have interest on beautiful things to make them understand that everything is beautiful. Parents are often found imitate their child imperfect pronunciation (Javanese: pelo). This parents' bad act will make obstacles to the child's development. The child will be disappointed that others cannot understand what he is trying to say, finally child and parents will have quarrelsome. It is better for parents to guide the children to have the clear utterances. (Suryomentaram, et al., 1985).

The study of Kawruh Pamomong has been discussed in relation to increasing the society's moral values to anticipate the effect of Indonesian demography (Wicaksono \& Priyanggasari, 2016). The in depth study has been conducted by Muniroh (2018), she stated that Kawruh Pamomong of KAS consists of moral principles to increasing the empathy education to children. Those two ideas are the result of contemplation about Kawruh Pamomong KAS, and has not been in the level of the practice of the implementation of Kawruh Pamomong KAS. There is a district in Yogyakarta in which the Kawruh Pamomong has been implemented. This research reveals the facts on parent's way to educate children in order they can think and act properly, lovely and beautifully through the local system, Kawruh Pamomong initiated by KAS. This research is expected to be able to enrich theoretical aspects regarding children education by applying the local wisdom, like what has been conducted by Ki Hadjar Dewantara through Among System or Ki Ahmad Dahlan with his Muhammadiyah.

\section{METHOD}

Survey method is employed in this research. 95 children of elementary school age in Balong District are employed as the research population. The research samples are 30 children and adolescences in Balong sub-district. The samples were gain randomly. The data were gained from questionnaire. The big lines of questionnaire refer to the KAS ideas regarding Kawruh Pamomong, how parents educate the children to think and act properly, affectionately, and beautifully. The following Table 1 is the big lines being used in this research. Expert judgement was employed as the data validity. The meant experts are the experts on Kawruh Pamomong KAS. Data reliability was conducted by recording the survey which is guided by $\mathrm{Ki}$

Tabel 1. Big lines of Kawruh Pamomong according to KAS

\begin{tabular}{|c|c|c|}
\hline $\begin{array}{l}\text { No. } \\
\end{array}$ & Aspect & Indicator \\
\hline 1. & $\begin{array}{l}\text { Educate children to be able to } \\
\text { think and understand the right } \\
\text { things (Lare dipunudi ngantos } \\
\text { sumerep (ngertos) dhateng } \\
\text { barang ingkang leres, tuwin } \\
\text { remen mikir ingkang leres) }\end{array}$ & $\begin{array}{l}\text { Training the children to know things properly so that they will } \\
\text { possess the proper way of thinking (being rational and real). } \\
\text { Training the children to differentiate between hard to see (raos } \\
\text { weruh) and presume to see (raos ngiro weruh), } \\
\text { Train the children to differentiate between real knowledge (kawruh } \\
\text { nyata) with the assumption/people' assumption (kawruh jare- } \\
\text { jarene). }\end{array}$ \\
\hline 2. & $\begin{array}{l}\text { Educate children to be able to } \\
\text { love others (Lare kaudi sagedo } \\
\text { anggadhahi sih dhateng tiyang } \\
\text { sanes) }\end{array}$ & $\begin{array}{l}\text { Training The children to grow the side of passion to others. } \\
\text { sadaya kakarepan tuwin pandaleman ingkang sarwo sepen ing } \\
\text { pamrih } \\
\text { Free of self-interest (sepi ing pamrih) } \\
\text { saged ngraosaken raosipun tiyang sanes } \\
\text { sadaya kekarepan ingkang remen adamel kabegjan tiyang sanes }\end{array}$ \\
\hline 3. & $\begin{array}{l}\text { Educate children to have } \\
\text { interest on beautiful things } \\
\text { so that they understand that } \\
\text { everything is beautiful. } \\
\text { (Lare kaudi sageda remen } \\
\text { dhateng barang ingkang endah. } \\
\text { Lare sumerep yen sadaya } \\
\text { barang punika endah) }\end{array}$ & $\begin{array}{l}\text { Growing the interest on all beautiful things } \\
\text { Fixing the sense so that it is free from thought. } \\
\text { Accepting all the accepted from the senses, because it is natural. } \\
\text { Training the perspective of beautifulness based on its existence; } \\
\text { Trainer or teacher should speak properly, should not imitate the } \\
\text { imperfect children' pronunciation. }\end{array}$ \\
\hline
\end{tabular}


Prasetyo Atmosutidjo and Ki Gregorius Rajo from the school of Kawruh Jiwa KAS. Expert judgement was employed because the referred qualitative data has no scale. Those experts are the writers of The Handbook of Ilmu Kawruh Jiwa Suryomentaram in the Cultural Ministry of Yogyakarta. The researcher did not conduct the experiment to other kids in other place because the teaching of Kawruh Pamomong KAS exists only in Balong District with 30 students. The percentage and the most appeared answer would be used as the data analysis.

\section{RESULT AND DISCUSSION Result}

The research result comes from the analysis of questionnaire that were assigned to the 30 children and adolescences in Balong subdistrict. The first step of analysis was conducted by mapping the most-appeared answers regarding father and mother pattern to care the children from the three-perspectives of Kawuh Pamomong. Those are educating children to understand and act properly, educating children to understand, think and act according to the principle of passion and educating children to understand, think and act nice. The results would be explained as follows.

\section{Kawruh Pamomong: Think and Act Properly}

The first Kawruh Pamomong is to think and act properly. It means to educate children to know things properly so that the children will possess the proper thinking pattern (rational and real). In Javanesse is lare dipunudi ngantos sumerep (ngertos) dhateng barang ingkang leres, tuwin remen mikir ingkang leres. Table 2 is the answer of children the inhabitant of District of Balong in relation to the way mother and father to implement Kawruh Pamomong to think and act properly.

\section{Kawruh Pamomong: Think and Act based on Passionate or SIH}

The second Kawruh Pamomong is to think and act based on passionate 'SIH'. In Javanese, it says lare kaudi sageda anggadahi sih dhateng tiang sanes which means to educate children to be able to love others. The response of the children is revealed through the Table 3.

\section{Kawruh Pamomong: To Think and Act Gracefully}

The third Kawruh Pamomong is to educate children to think and act gracefully. In Javanese, it says, lare kaudi sageda remen dateng barang ingkang endah. Lare sumerep yen sadaya barang punika endah which means to educate children to have interest on beautiful things so that they understand that everything is beautiful. The response of the children is revealed through table 4 .

Children's response appropriateness in Balong District with the Theory of Kawruh Pamomong

The next step of the research is to find the appropriateness between the responses and the theory of Kawruh Pamomong which has been discussed in the Literature Review. Then, the result would be calculated to show the degree of correlations between the way mother and father to teach and educate children (Table 5).

\section{Discussion}

Children are born to this world with each physically and psychologically. Every child has a unique that parents should not treat all the same. Parents may have various strategies in educating their children. However, KAS had opinion that human feeling is all the same to others. What makes them different is the pattern of child nurturing and its strategy. KAS has offered Kawruh Pamomong as a way to educate children to make them happy. Kawruh Pamomong consists of three things, those are how to educate children to know, think and act properly, educate children to possess love to each others and educate children to know and act nice.

On Kawruh Pamomong, educating children to think and act properly, there are two things of educating based on KAS that are not conducted by father or mother as follows.

1) When a child ask something to parents, and the parents cannot answer it, $41.38 \%$ father let the child to ask to others and $34.48 \%$ choose to keep silent. According to the teaching of KAS, when parents could not answer the children's question, parents should make the children wait. This teaches children to be patient. Parents should try to find the answer to the experts. It is better that the answer points to the real and true, not something that 
Table 2. Children Answer Mood regarding Father/Mother way of educating the Children to Think and Act Properly

\begin{tabular}{|c|c|c|c|}
\hline \multirow{2}{*}{ No. } & \multirow{2}{*}{ Question } & \multicolumn{2}{|c|}{ Answer Mood Regarding Parents } \\
\hline & & Father (\%) & Mother (\%) \\
\hline 1 & $\begin{array}{l}\text { Have you ever been Afraid of Ghost by your } \\
\text { parents? }\end{array}$ & 79.31 answer no & 58.62 answer no \\
\hline 2 & $\begin{array}{l}\text { Have you ever been threatened by your parents? } \\
\text { Have your parents ever told lies to you? }\end{array}$ & 72.41 answer no & 62.07 answer no \\
\hline 3 & When you were an elementary student, asking & 62.07 answer no & 68.97 answer no \\
\hline 4 & $\begin{array}{l}\text { a question and your dad can not answer it, what } \\
\text { would he do? }\end{array}$ & $\begin{array}{l}41.38 \text { ask someone else to } \\
\text { answer. }\end{array}$ & 34.48 keep silent \\
\hline 5 & $\begin{array}{l}\text { When you were an elementary student, you felt } \\
\text { down, what would your dad do? }\end{array}$ & $\begin{array}{l}79.31 \text { to strengthen you, } \\
\text { that being fell down is } \\
\text { nothing to worry about. } \\
\text { Next time, I should be } \\
\text { more careful. }\end{array}$ & $\begin{array}{l}68.97 \text { to strengthen you, } \\
\text { that being fell down is } \\
\text { nothing to worry about. } \\
\text { Next time, I should be } \\
\text { more careful. }\end{array}$ \\
\hline 6 & $\begin{array}{l}\text { When you were an elementary student, did your } \\
\text { parents feed you? }\end{array}$ & 89.66 answer no & 65.52 answer no \\
\hline 7 & $\begin{array}{l}\text { When your dad tried to stop feed you, what did } \\
\text { he try to say to you? }\end{array}$ & 41.38 this is embarashing & 55.17 this is embarashing \\
\hline 8 & $\begin{array}{l}\text { When you were an elementary student, when } \\
\text { you planned to back to your home, what would } \\
\text { your parents do? }\end{array}$ & $\begin{array}{l}41.38 \text { let you to come } \\
\text { home by you yourself }\end{array}$ & 41.38 picked you up \\
\hline 9 & $\begin{array}{l}\text { When you were an elementary student, did your } \\
\text { parents teach you patiently by providing proper } \\
\text { understanding based on reality? }\end{array}$ & 68.97 answer yes & 86.21 answer yes \\
\hline 10 & $\begin{array}{l}\text { When you were an elementary student, you } \\
\text { were carried in your uncle hips. In fact, you } \\
\text { rejected it. Did your parents say, don't you want } \\
\text { to be carried by your uncle? Is he naughty? Let } \\
\text { me pinch him so that he will not be naughty } \\
\text { anymore. }\end{array}$ & 93.10 answer no & 96.55 answer yes \\
\hline 11 & $\begin{array}{l}\text { What would your parents say when you rejected } \\
\text { to be carried by that neighbour? }\end{array}$ & $\begin{array}{l}44.83 \text { answer "Never } \\
\text { mind, it is peaceful being } \\
\text { carried by him". }\end{array}$ & $\begin{array}{l}41.38 \text { answer, "Never } \\
\text { mind, it is peaceful being } \\
\text { carried by him". }\end{array}$ \\
\hline 12 & $\begin{array}{l}\text { When you were an elementary student, you did } \\
\text { not want to take a bath. What would your parents } \\
\text { say and do? }\end{array}$ & 62.07 giving motivation & 58.62 giving motivation \\
\hline 13 & $\begin{array}{l}\text { When you were an elementary student, What } \\
\text { did your parents ask that made you afraid for } \\
\text { not doing it? }\end{array}$ & 37.93 doing the religion & 58.62 doing the religion \\
\hline 14 & $\begin{array}{l}\text { When you were an elementary student, you } \\
\text { broke thing in your house, what would your } \\
\text { parents do? }\end{array}$ & $\begin{array}{l}37.93 \text { only asking us to } \\
\text { clean up and explaining } \\
\text { about the danger of not } \\
\text { cleaning it. }\end{array}$ & $\begin{array}{l}37.93 \text { only asking us to } \\
\text { clean up and explaining } \\
\text { about the danger of not } \\
\text { cleaning it. }\end{array}$ \\
\hline 15 & $\begin{array}{l}\text { When you were an elementary student, you } \\
\text { played a knife or dagger. What would your } \\
\text { parents do? }\end{array}$ & $\begin{array}{l}\text { 44. } 83 \text { letting you to play } \\
\text { them and explaining that a } \\
\text { knife can hurt you. }\end{array}$ & $\begin{array}{l}41.58 \text { letting you to play } \\
\text { them and explaining that } \\
\text { a knife can hurt you. }\end{array}$ \\
\hline 16 & $\begin{array}{l}\text { When you were an elementary student, what } \\
\text { action did your parents prohibit? }\end{array}$ & 13.79 hurt parents & $\begin{array}{l}13.79 \text { not involving in } \\
\text { religion activities. }\end{array}$ \\
\hline 17 & $\begin{array}{l}\text { When you wanted to go with parents when } \\
\text { they wanted to go for working, what would } \\
\text { they do? }\end{array}$ & $\begin{array}{l}44.83 \text { honestly said that } \\
\text { they will go for work }\end{array}$ & $\begin{array}{l}37.93 \text { honestly said that } \\
\text { they will go for work }\end{array}$ \\
\hline 18 & $\begin{array}{l}\text { When you, still, wanted to go with parents to go } \\
\text { for working, what would they do? }\end{array}$ & $\begin{array}{l}41.38 \text { go for work while } \\
\text { explaining why they } \\
\text { should go for work. }\end{array}$ & $\begin{array}{l}44.83 \text { go for work while } \\
\text { explaining why they should } \\
\text { go for work }\end{array}$ \\
\hline
\end{tabular}


Table 3. Father and Mother Answer Mood Regarding Thinking and Act "Sih"

\begin{tabular}{|c|c|c|c|}
\hline \multirow{2}{*}{ No. } & \multirow{2}{*}{ Question } & \multicolumn{2}{|c|}{ Mood } \\
\hline & & Father & Mother \\
\hline 1 & $\begin{array}{l}\text { When your toys were borrowed by a friend, } \\
\text { what would your father and mother do? }\end{array}$ & $\begin{array}{l}82.76 \text { ask me to let it } \\
\text { go, explaining that we } \\
\text { should share and love to } \\
\text { each others. }\end{array}$ & $\begin{array}{l}79.31 \text { ask me to let it } \\
\text { go, explaining that we } \\
\text { should share and love to } \\
\text { each others. }\end{array}$ \\
\hline 2 & $\begin{array}{l}\text { When you were an elementary student, you } \\
\text { had a quarrelsome with friend, what would } \\
\text { your parents do? }\end{array}$ & $\begin{array}{l}44.83 \text { giving } \\
\text { understanding to the } \\
\text { children about the effect } \\
\text { of quarrelsome }\end{array}$ & $\begin{array}{l}34.48 \text { giving } \\
\text { understanding to the } \\
\text { children about the effect } \\
\text { of quarrelsome }\end{array}$ \\
\hline 3 & $\begin{array}{l}\text { When you were an elementary student, there } \\
\text { was a friend of yours that failed to pass the } \\
\text { grade, what would your father and mother do } \\
\text { to you? }\end{array}$ & $\begin{array}{l}34.48 \text { giving } \\
\text { understanding to you that } \\
\text { everybody has different } \\
\text { abilities. }\end{array}$ & $\begin{array}{l}34.48 \text { giving } \\
\text { understanding to you that } \\
\text { everybody has different } \\
\text { abilities. }\end{array}$ \\
\hline 4 & $\begin{array}{l}\text { When you were an elementary student, you } \\
\text { were asked to join humanity activities such as } \\
\text { work cooperatively, help the neighbour, giving } \\
\text { charity and soon, what would your father and } \\
\text { mother say? }\end{array}$ & $\begin{array}{l}34.48 \text { come, join father. } \\
\text { When we help others, } \\
\text { someday others will help } \\
\text { us. }\end{array}$ & $\begin{array}{l}44.83 \text { come, join father. } \\
\text { When we help others, } \\
\text { someday others will help } \\
\text { us. }\end{array}$ \\
\hline 5 & $\begin{array}{l}\text { When you were an elementary student, how } \\
\text { often did your mother and father give you } \\
\text { credit? }\end{array}$ & 31.09 answer never & 31.03 once a day \\
\hline 6 & $\begin{array}{l}\text { When you had your puberty and had interest } \\
\text { to other gender, what would your father and } \\
\text { mother do and say? }\end{array}$ & $\begin{array}{l}31.03 \text { keep silent because } \\
\text { that is natural }\end{array}$ & 31.03 get worry \\
\hline 7 & $\begin{array}{l}\text { When you were an elementary student, have } \\
\text { your father and mother ever compared you to } \\
\text { someone else? }\end{array}$ & 62.07 answer never & 72.41 answer never \\
\hline 8 & $\begin{array}{l}\text { When you were an elementary student, have } \\
\text { your parents ever made you shy in front of } \\
\text { others? }\end{array}$ & 96.56 answer sometimes & 100 answer sometimes \\
\hline 9 & $\begin{array}{l}\text { What did your parents expect from you when } \\
\text { you were an elementary student? }\end{array}$ & $\begin{array}{l}27.59 \text { becomes a class } \\
\text { champion }\end{array}$ & $\begin{array}{l}24.14 \text { becomes a class } \\
\text { champion }\end{array}$ \\
\hline 10 & $\begin{array}{l}\text { What would your parents expect from you } \\
\text { when you are grown up? }\end{array}$ & $\begin{array}{l}34.48 \text { high level of } \\
\text { education }\end{array}$ & $\begin{array}{l}41.59 \text { high level of } \\
\text { education }\end{array}$ \\
\hline
\end{tabular}

is uncertainty (Suryomentaram, et al., 1985). If the answer is directed to the realistic, there is possibility that everyone will answer the same. However, if the answer is directed to unrealistic, everybody will have different answers. This is the cause of quarrelsome.

2) The words that coming from father and mother regarding asking a child to stop being feed are $41.38 \%$ from father and $55.17 \%$ from mother who stated that it is embarrassment. That kind of answer brings bad impact to children that they will feel that they are being compared to friends. The feeling of being compared is the 15 obstacles of feeling love based on KAS (Suryomentaram, et al., 1985). This brings uncomforted between children and parents.
This feeling brings quarrelsome. It is better for parents to tell the children that they have own hand, functioning putting food to mouth. Such kind of answer will get the children accustomed to think real and proper.

In table 2, it is revealed that parents in Balong District share the common worries regarding the children's obedience to do the religion's requirements, which is Islam. All of the district's inhabitants are Muslims. For $58.62 \%$ of mothers are more worried if the children do not obey the Islam teaching than fathers for $37.93 \%$. The referred teachings of Islam in this research are including fasting, praying, giving religious meal and reading Qur'an. If the children obey the teaching of the religion, they will grow as good 
Table 4. Father and Mother Answer Mood Regarding Think and Act Beautiful

\begin{tabular}{|c|c|c|c|}
\hline \multirow{2}{*}{ No. } & \multirow{2}{*}{ Question } & \multicolumn{2}{|c|}{ Mood } \\
\hline & & Father & Mother \\
\hline 1 & $\begin{array}{l}\text { When you were an elementary student, what } \\
\text { kind of scent did your parents introduce to } \\
\text { you? }\end{array}$ & 37.93 flower scent & 48.28 flower scent \\
\hline 2 & $\begin{array}{l}\text { When you were an elementary student, } \\
\text { what would your parents do when there was } \\
\text { someone had fart with the bad smell? }\end{array}$ & $\begin{array}{l}48.28 \text { keep silent and let } \\
\text { it go. }\end{array}$ & $\begin{array}{l}48.28 \text { keep silent and let } \\
\text { it go. }\end{array}$ \\
\hline 3 & $\begin{array}{l}\text { When you were an elementary student, what } \\
\text { kind of sound did your parents teach to you? }\end{array}$ & 55.17 thunder & 55.17 thunder \\
\hline 4 & $\begin{array}{l}\text { When hearing thunder, what would your } \\
\text { parents do? }\end{array}$ & 65.52 closing ears & 72.41 closing ears \\
\hline 5 & $\begin{array}{l}\text { When you were an elementary student, what } \\
\text { kind of beautiful thing that your parents } \\
\text { introduce to you? }\end{array}$ & 37.93 rainbow & 37.93 rainbow \\
\hline 6 & $\begin{array}{l}\text { When the day was cloudy, what would your } \\
\text { parents do? }\end{array}$ & $\begin{array}{l}37.93 \text { giving } \\
\text { understanding that } \\
\text { cloudy is beautiful also. }\end{array}$ & $\begin{array}{l}44.83 \text { giving } \\
\text { understanding that } \\
\text { cloudy is also beautiful. }\end{array}$ \\
\hline 7 & $\begin{array}{l}\text { When you were an elementary student, what } \\
\text { were tasted-things introduced to you by your } \\
\text { parents? }\end{array}$ & 17.24 the sweet of sugar & 24.14 the sweet of sugar \\
\hline 8 & $\begin{array}{l}\text { When you felt the sour or bitter that are not } \\
\text { favourite tastes, what would your parents do? }\end{array}$ & $\begin{array}{l}34.48 \text { giving } \\
\text { understanding that the } \\
\text { un-favourite taste is also } \\
\text { beautiful. }\end{array}$ & $\begin{array}{l}37.93 \text { giving } \\
\text { understanding that the } \\
\text { un-favourite taste is also } \\
\text { beautiful. }\end{array}$ \\
\hline 9 & $\begin{array}{l}\text { When you were an elementary student, } \\
\text { the soft and hard-texture things that were } \\
\text { introduced to you by parents are? }\end{array}$ & 37.93 skin & 41.38 skin \\
\hline 10 & $\begin{array}{l}\text { When you felt something that you did not like } \\
\text { such as pebble, what would your parents do? }\end{array}$ & $\begin{array}{l}34.48 \text { giving } \\
\text { understanding that the } \\
\text { hard texture that most of } \\
\text { us don't like is beautiful. }\end{array}$ & 31.03 keep silent \\
\hline
\end{tabular}

Tabel 5. The Properness of Parents Education with Kawruh Pamomong of KAS in Balong SubDistrict

\begin{tabular}{|c|c|c|c|c|c|c|c|c|}
\hline \multicolumn{3}{|c|}{ Think and Act Right } & \multicolumn{3}{|c|}{ Think and Act"Sih" } & \multicolumn{3}{|c|}{ Think and Act Nice } \\
\hline No. Item & Father & Mother & No. Item & Father & Father & No. Item & Father & Mother \\
\hline 1. & Proper & Proper & 1. & Proper & Proper & 1. & Proper & Proper \\
\hline 2. & Proper & Proper & 2. & Proper & Proper & 2. & Proper & Proper \\
\hline 3. & Proper & Proper & 3. & Proper & Proper & 3. & Proper & Proper \\
\hline 4. & Improper & Improper & 4. & Proper & Proper & 4. & Proper & Proper \\
\hline 5. & Proper & Proper & 5. & Improper & Proper & 5. & Proper & Proper \\
\hline 6. & Proper & Proper & 6. & Proper & Improper & 6. & Proper & Proper \\
\hline 7. & Improper & Improper & 7. & Proper & Proper & 7. & Proper & Proper \\
\hline 8. & Proper & Improper & 8. & Proper & Proper & 8. & Proper & Proper \\
\hline 9. & Proper & Proper & 9. & Improper & Improper & 9. & Proper & Proper \\
\hline 10. & Improper & Proper & 10. & Improper & Improper & 10. & Proper & Improper \\
\hline 11. & Improper & Proper & & & & & & \\
\hline 12. & Proper & Proper & & & & & & \\
\hline 13. & Proper & Proper & & & & & & \\
\hline 14. & Proper & Proper & & & & & & \\
\hline 15. & Proper & Proper & & & & & & \\
\hline 16. & Proper & Proper & & & & & & \\
\hline 17. & Proper & Proper & & & & & & \\
\hline 18. & Proper & Proper & & & & & & \\
\hline Proper (\%) & 83 & 83 & & 70 & 70 & & 100 & 90 \\
\hline Improper $(\%)$ & 17 & 17 & & 30 & 30 & & 0 & 10 \\
\hline
\end{tabular}


people. Becoming good people is what parents want and expect from the children as Snouk Hurgronie, a Dutch researcher, writes about Islam in Indonesia in 1892 (Geertz, 1985).

In table 4, parents in Balong District introduce the beautifulness through introducing their children to the God's creations such as flowers, lightning and rainbow. According to KAS, the way to educate children about the beautifulness is by introducing them to the beautiful things and making them understand that all things in this world are beautiful. When the children understand that all things are beautiful, they will have passion to all things. The love will attract passion, the act of keeping and maintaining of all things. Covey (1997) stated that there are 4 principles of family roles, they are modeling, mentoring, organizing and teaching. As $65.52 \%$ of mothers and $72.41 \%$ of fathers cover ears when there is thunder and the children will imitate them. According to Covey (1997), the function of modeling is the reason why the children imitate the parents.

Different answers given regarding how to educate and think and also proper act shown by the question of "when you were an elementary student, you are cared in hip by neighbor but you rejected it. Did your father or mother ever say "I will pinch your uncle so that he will not be naughty anymore". There are $93.10 \%$ father did not respond like that, $96.55 \%$ of mother did it. It indicates that father applied the teaching of KAS, but not the mother. According to KAS, the educated answer when the children reject to be taken care in hip is to say the truth, uncle does not naughty, but he loves children.

According to the result of questionnaire recapitulation in Table 5, it indicates that 18 questions regarding teaching and training children to think and act properly, the answers that correspond with KAS teaching are 15, and the ones that not suitable with KAS are 3. It is revealed that in educating children to think and act properly in Balong Sub-district, father and mother implemented the teaching of KAS.

It is obligated that parents should teach "sih" to others. Table 3 indicates that the existence differences in educating, between father and mother. That is how often that father and mother give opinion regarding the children have interest on different sex. $31.09 \%$ that father never gives credit and $31.03 \%$ that mother gives credit once a day. There is reason why father never gives credit compared to the mother, in patrilineal, women are labeled as the creature that talks to much. This is the reason why when a man is talkative, he will be labeled as woman (Juliano, 2015). Woman has the ability to speak much more than a man. Woman talks 20,000 words and man talks for 7,000 words as stated by Falatehan \& Kusumah (2018). Different answers were found when the children are asked about reaction (behavior, statement and act) of father and mother when their son are having puberty and start to have interest to other gender. $31.03 \%$ of father kept silent. He thought that it is natural. 31.03 made her mother worries. The act of father that it is natural that in woman likes man and vice versa. Mother is the one that protects the children, although, according to KAS, it is considered as not-good-behavior. The early sex education is most important thing to protect the children in this millennial era. Jatmikowati, Angin, \& Ernawati (2015) gives solution for mother's worry by stating the early sex education.

Early sex education does not tell and teach free sex when the children grown up. It is intended that they understand about the characteristic of their body, another gender's, and keep the children away from sexual ahrrasments...

(Jatmikowati, et. al., 2015)

The answers regardingparents'expectation for the children when they were in elementary school are $27.59 \%$ father and $24.14 \%$ mother expect that the children become the champion of the class academically. The answers regarding father and mother expectation when the children have grown up are $34.48 \%$ father and $41.59 \%$ mother want that the children will have the high level of education. If we trace back the teaching of KAS, those parents' answers are not proper/ suitable. The proper answer of the parents should be good characters, so that the children will get along with others and make them easy to earn life. In simple words, KAS does not make the academic achievement as the central issue. More important than that the children will have passion and love so that they will get along with others comfortably. KAS did not expect that the children will be the ones that have the burden when the parents are retired. Education should 
be based on the children needs, not the parents' (Suryomentaram, 2015). Although the parents' respond do not correspond the KAS teaching, it indicates that parents realized that school is important. The more parents understand the education, the more parents' desire to send the children to school (Bunu, 2014). The supporting research comes from Lee \& Bowen (2006), it shows that parents' participation at school and the high education expectation reveals the strong relationship with the education achievement.

Based on the recapitulation of the education of father and mother using Kawruh Pamomong in Balong Sub-District on table 5, it indicates that father and mother mostly use the same ways to educate children to love others or "sih" by reffering to the teaching of KAS. It is proven from 10 questions regarding educating and teaching "sih", there are 7 questions for father and mother in Balong Sub-District which are suitable with the education of "sih" from KAS, and there are 3 that not suitable with KAS's. The different teaching and nurturing styles between father and mother becomes something acceptable in the culture of Javanese because the Patrilinialism does exists as stated by Darwin (1999). In Javanese culture, father is described normatively as the wise leader family, respected and loveable, close to the children and becomes the one that would be the helper for others. Between father and son there is formal and awkward environment (Magnis-Suseno, 1985).

Darwin (1999) stated that, in Javanese perspective, the ideal man is the one who has money and sexual orientation. Woman belongs to man, can be equally stated as money, home, vehicle, pets and weapon. The woman colonialism is the power symbol for man. On the other hand, woman is dependent. Being obedient is the noble of the woman. Although nowadays there is shift perspectives on man and woman, social and culture of the Javanese has been rooted, so that the perspectives do not change much. This has been stated by Uyun (2002) who conducted research in Surakarta as the representation of royal family and in Limbangan Klaten who represents the people of Javanese in villages. As what happened in Balong, the stereotype influences the nurturing pattern to children.

The description of father on nurturing and educating is by stating less in form of suggestion, understanding and real examples. The stereotype as Darwin (1999) has stated about father is that he is fatherhood and there is violence. Those would be inherited. According to the Western theories, Javanese prefers to apply the behaviourism to form the behaviour (Rusuli, 2014) than to develop the act such as in Constructivism which denies the behaviorism.

There are slightly difference between the way father and mother teach the children to think and act nice, although both of them applied KAS' Kawruh Pamomong. The difference is on the act of father and mother for the question of feeling something that is not ok, such as stone in the way. $34.48 \%$ of father gives understanding that the hard texture is also beautiful and $31.03 \%$ of mother keep silent. Father's respond is suitable with KAS', but not the mother's. According to the recapitulation of table 5, most of parents in Balong teach and educate children by implementing KAS' Kawruh Pamomong. It is proven that from 10 questions, 9 questions are suitable with KAS'. There is only one that is not suitable. Suriansyah \& Aslamiah (2016) proposed the communication and effective partnership which are used as parents' strategies to build students' characters.

There is no difference on nurturing between father and mother in Balong District in terms of ethic, such as respect to parents and being harmonious with neighbours. This is in accordance with the statement of Hildred Greetz in Magnis-Suseno (1985) that the children of Javanese learn, wedi (afraid), isin (shy) and sungkan (pretending to say no). Those three elements support psychologically to the expectation of respectful principles. It is expected that every human eager to respect, the bad act resulted on inconvenience. Wedi means afraid, both to physically and mentally of doing something not properly. Isin means shy. Learn to shy means the first step to the Javanese maturity. Sungkan means respect to the elder and the ones who have not been known yet. Although Nolthe \& Harris (1998) teaches that children who are shy, they learn to feel guilty. To Javanese, to be shy is important to hold up the conflict.

Parents in Balong District nurture the children with the low intonation, not rudely. Moreover for mother, Javanese people believe that mother's saying or statement is a pray to the God. The proper language between parents and 
children is a way to hold up the conflicts. This is described by Magnis-Suseno (1985) that in Javanese, there is a way to hold up the conflict is by teaching the norms. The Javanese norms regulate all kinds interaction happens outside core family and friend environments. The norms include the body movement, the steps to sit, content of talks and the forms of talks. The Javanese language is proper for those, for example, talks among civilized people should obey the norms because the norms will not give the space for the rude talks and show the anger.

Emotion approach will not give impact on stress to children during their process to know the surroundings. On the other hand, the surroundings full of stress will develop aggression on children as showed by the research of Attar, Guerra, \& Tolan (1994) who research on surrounding's lost, full stress life for Hispanic children who live in cities.

The ability to act based on norms is learned by the children of Javanese in family. Geertz labeled this kind of education as the Javanese children obedience consisting of two steps (Magnis-Suseno, 1985). The first step, happens until the children are five and signed by the close relationship with family, there is no string and hesitance. During that time, the children would be the focus of the family. The children would be on physical contacts with mother, father, brother, grandma, grandpa and other relatives. Experience on frustration, negative shocks are prevented and all the willing are welcome. All dangers and obstacles are taken away, even the mystical things. The second step happens when the children are above 5 . In this step, father would be stranger, children should be afraid of him. The children should learn the norms from the adults in surroundings.

The teaching of Kawruh Pamomong written by KAS in 1920's supported by Covey in 1997 wrote 7 Habits of Highly Effective Families. Effective Family is "a beautiful family culture". The beautiful culture of a family consists of (1) the spirit of family, feeling, family atmosphere, (2) family character, the in depth quality of relationship, (3) the way of family members to make relation with other members and how they feel about the relation itself, (4) the feeling that develops the pattern of collective behaviors which indicate the family interaction. Covey (1997) stated that nice or beautiful family stated themselves as 'we' not the 'I' in relation to the concept of family.

Covey (1997) stated that the happiness emerges from other's happiness, meaning that those family members are moving from ' $I$ ' to 'we'. That condition is defined as 'culture' and if it is maintained, it will be turn into beautiful culture. According to KAS, the moving from ' $\mathrm{I}$ ' to 'we' is called 'Raos Sami'. This Raos Sami will emerge the passion or 'raos sih' in every human soul to everything and soul of the God's creations. For the inhabitants of Balong District, the interaction among family members which guided by Kawruh Pamomong produces the independent character and passionate in the children's souls.

\section{CONCLUSON}

Family education in Sub District of Balong, Sewon, Bantul is the education that implements Kawruh Pamomong of KAS'. Father has more Pamomong soul on the aspect of teaching children to think and act nice, compared to the mother. Father has the same soul of Pamomong with mother in case of teaching children to think and act properly based on "sih" or love. It is better that research regarding KAS still go on. There are a lot of other topic regarding KAS, for example, what are the parents' strategy to face KAS values at home which are different to values at school.

\section{ACKNOWLEDGEMENT}

The researcher say thank you to the ministry of Research Technology and Higher Education. The researcher will also say thank you to LPPM UPY that facilitates the research processes. The researcher will also say thank you to the citizens of Balong Sub District that cooperate for this research.

\section{REFERENCES}

Attar, B. K., Guerra, N. G., \& Tolan, P. H. (1994). Neighborhood disadvantage, stressful life events and adjustments in urban elementary-school children. Journal of Clinical Child Psychology, 23(4), 391400. doi:10.1207/s15374424jccp2304_5.

Bunu, H. Y. (2014). Kesadaran masyarakat suku dayak terhadap pendidikan anak di pedalaman Kalimantan Tengah. 
Cakrawala Pendidikan, 33(3), 445-453. doi:10.21831/cp.v3i3.2288.

Covey, S. R. (1997). The 7 habits of highly effective families. New York, NY: St. Martin's Griffin.

Darwin, M. (1999). Maskulinitas: Posisi lakilaki dalam masyarakat patriarkis. Center for Population and Policy Studies Gadjah Mada University, 4, 1-10.

Falatehan, N., \& Kusumah, E. (2018). The overview of the esthetics and phonetic satisfaction rate of complete denture patients at Faculty Of Dentistry Trisakti University. Cakradonya Dental Journal, 10(2), 102-106.

Geertz, H. (1985). Keluarga Jawa. Jakarta: Grafiti Pers.

Ghufron, A., Budiningsih, A., \& Hidayati, H. (2017). Pengembangan pembelajaran berbasis nilaibudaya Yogyakarta di sekolah dasar, Cakrawala Pendidikan, 36(2), 309319. doi:10.21831/cp.v36i2.12449.

Harjaningrum, A. T. Inayati, D. A., Wicaksono, H. A., \& Derni, M. (2007). Peran orang tua dan praktisi dalam membantu tumbuh kembang anak berbakat melalui pemahaman teori dan trend pendidikan. Jakarta: Prenada Media Grup.

Ishomuddin, I. (2014). Construction of sociocultural and political orientation of the followers of Muhammadiyah and Nahdlatul Ulama (NU) in the post reform era in East Java Indonesia. Global Journal of Politics and Law Research, 2(2), 3951.

Jatmikowati, T. E., Angin, R., \& Ernawati, E. (2015). Model dan materi pendidikan seks anak usia dini perspektif gender untuk menghindari sexual abuse. Cakrawala Pendidikan, 34(3), 434-448. doi:10.21831/ cp.v3i3.7407.

Juliano, S. (2015). Komunikasi dan gender: Perbandingan gaya komunikasi dalam budaya maskulin dan feminim. Jurnal Ilmu Politik dan Komunikasi, 5(01), 1930. doi:10.33867/JIPSI.V5I01.153.

Koentjoro, K. (2015). Ki Ageng Suryomentaram (1892-1962) guru psikologi eksistensialis nusantara: Belajar mindfullness tanpa meditasi. In R. Sugiharto (Ed.), Psikologi Raos (pp. 7-16). Yogyakarta: Pustaka Ifada.

Kusumawardhani, W. (2018). Self-introspection in the search of identity in Serat Jayengbaya by Ranggawarsita. IOP Conference Series: Earth and Environmental Science, 175(1), 012114, 1-6. doi:10.1088/1755$1315 / 175 / 1 / 012114$

Lee, J-S., \& Bowen, N. K. (2006). Parent involvement, cultural capital, and the achievement gap among elementary school children. American educational research journal, 43(2), 193-218. doi:10.3102/00028312043002193.

Magnis-Suseno, F. (1985). Etika Jawa: Sebuah analisa filsafi tentang kebijaksanaan hidup Jawa. Jakarta: Gramedia Pustaka Umum.

Muniroh, A. (2018, April). Kawruh Pamomong Ki Ageng Suryomentaram: Prinsip-prinsip moral untuk mengoptimalkan pendidikan empati pada anak. In Proceedings of Annual Conference for Muslim Scholars (No. Series 2, pp. 742-750).

Nolthe, D. L. \& Harris, R. (1998). Children learn what they live, parenting to inspire value. New York, NY: Workman Publishing.

Rusuli, I. (2014). Refleksi teori belajar behavioristik dalam perspektif islam. Jurnal Pencerahan, 8(1), 38-54. doi:10.13170/jp.8.1.2042.

Subagya, S. (2016). Ki Hadjar Dewantara menawarkan masa depan. Yogyakarta: Pohon Cahaya.

Sugiarto, R. (2015). Handbook ilmu kawruh jiwa suryomentaram riwayat dan jalan menuju 
bahagia. Yogyakarta: Dinas Kebudayaan Daerah Istimewa Yogyakarta.

Suriansyah, A. \& Aslamiah, A. (2016). Strategi kepemimpinan kepala sekolah, guru, orang tua dan masyarakat dalam membentuk karakter siswa. Cakrawala Pendidikan, 34(2), 234-247. doi:10.21831/ cp.v2i2.4828.

Suryomentaram, G. (2015). Kawruh jiwa wejanganipun Ki Ageng Suryomentaram; Kaimpun dening Ki Grangsang Suryomentaram. Jakarta: Haji Masagung.

Suryomentaram, G., Suastika, O., \& Armosentono, M. (1985). Ajaran-ajaran Ki Ageng Suryomentaram II. Jakarta: Inti Idayu Press.

Suryomentaram, G. (1989). Kawruh jiwa jilid $i$ wejanganipun Ki Ageng Suryomentaram. Jakarta: Inti Idayu Press.
Uyun, Q. (2002). Peran Gender dalam Budaya Jawa. Psikologika, 7(13), 32-42. doi:10.20885/psikologika.vol7.iss13.art3.

Wicaksono, D. E. \& Priyanggasari, A. T. S. (2016). Kawruh pamomong KAS (Ki Ageng Suryamentaram): Nilai-nilai moral untuk optimalisasi bonus demografi. Seminar Asean, $2^{\text {nd }}$ Psychology \& Humanity Psychology Forum UMM (pp. 95-101).

$\mathrm{Wu}$, S. (2018, Februari). 10 negara dengan sistem pendidikan terbaik di dunia. Retrieved from https://www.idntimes.com/life/ education/suci-wu-1/negara-dengansistem-pendidikan-terbaik-di-dunia-c1c2/ full.

Wusana, S. W. (2015). Ki Ageng Suryomentaram dari Yogyakarta untuk dunia: Riwayat dan jalan penemuan ilmu kawruh jiwa. Sugiarto, R (Ed.), Handbook Ilmu Kawruh Jiwa: Suryomentaram, Riwayat dan Jalan Menuju Bahagia. Yogyakarta: Dinas Kebudayaan Daerah Istimewa Yogyakarta. 